To cite this article: Saturday U. Omeluzor, Molokwu Ugochi \& Victoria Kelechi Izuakolam. (2020) Assessing the Use of Innovative Tools for Library Instruction and Services in Federal Universities Libraries in South-South. Nigeria. Information Impact: Journal of Information and Knowledge Management, 11:4, 92-106, DOI: https://dx.doi.org/10.4314/iiijkm.v11i4.9

To link to this article: https://dx.doi.org/10.4314/iijikm.v11i4.9

\title{
Assessing the Use of Innovative Tools for Library Instruction and Services in Federal University Libraries in South-South, Nigeria
}

\author{
${ }^{1}$ Saturday U. Omeluzor \\ 2 Molokwu Ugochi \\ ${ }^{3}$ Victoria Kelechi Izuakolam \\ ${ }^{1}$ Federal University of Petroleum Resources Library, Effurun, Nigeria \\ ${ }^{2}$ Federal College of Fisheries and Marine Technology, Nigeria \\ ${ }^{3}$ Clifford University Library, Ihie, Abia State Nigeria
}

\begin{abstract}
The study investigated the adoption of innovative tools for library instruction and services in Federal University libraries in South-South zone of Nigeria. The study cut across six federal university libraries in the zone with a total population of 93 academic librarians. The findings revealed that fewer numbers of the respondents have adopted and used innovative tools for library instruction and services which majority of the respondents are yet to use innovative tools for instruction and service delivery. It also showed that the frequency of use of the tools were staggered with social media and text messaging being the ones that are used daily, email was used on a weekly basis while Library Blog, website and OPAC were mostly used on quarterly basis and a general none use of radio broadcasting. The findings further indicated that inadequate use of innovative tools would affect patronage and adequate delivery of library instruction and services to the library patrons who are in different geo-political locations. The researchers recommended the need for library management in federal universities in the South-South zone of Nigeria to explore viable innovative tools for ilibrary instruction and services,
\end{abstract}

Keywords Innovative tools, Library instruction, Library services, Librarians, University libraries

CONTACT Saturday U. Omeluzor, Molokwu Ugochi. and Victoria Kelechi Izuakolam omeluzor.Saturday@fupre.edu.ng Federal University of Petroleum Resources Library, Effurun, Nigeria, Federal College of Fisheries and Marine Technology and Clifford University Library, Ihie, Abia State, 


\section{Introduction}

The advancement in information technology enhancing information access and dissemination opens a vista for the adoption of innovative tools for the provision of library instruction and services to the library patrons. All over the world, the use of information and communication technology (ICT) tools for the delivery of information services couple with the demand for self service tools is paving the way for the adoption of innovative tools for library instruction and delivery of services. The adoption of ICT in library services is expanding the mandate handed down to the library which would require the use of innovative tools in the delivery of library services. Today, library is functioning as a knowledge and support centre for learning, teaching and research for its parent institution. Library instruction is one of the core activities that academic library all over the world engages the library users that helps them to know the rules and regulations, how to access, locate, retrieve and use information sources which to an extent determine the success of students in learning and research. Library instruction otherwise known and referred to as 'user education' and 'information literacy is a well planned academic program that is designed by the university library for the purpose of sensitization, creating awareness and educating new and potential library patrons. In a post COVID19, the use of innovative tools would enable the delivery of library instruction without convergence of the patrons. In the past, the university library spend time in planning on the best approach that is suitable to educate its patrons in order to increase their level of awareness and use of information sources. The outbreak of COVID-19 pandemic is causing a lot of crisis in the educational sector that is encouraging the use of innovative tools in the delivery of services to bridge the gap. Hence the adoption of innovative tools in post COVID-19 would be more strategic in breaking barrier and reaching a wider audience simultaneously.

Observation has shown that the instructional methods adopted by most university libraries in Nigeria is only limited to classroom teaching, users' guide, orientation, library tour, referral services, one-on-one guidance, mentoring and reference services without the use of innovative tools. The National Universities Commission (NUC) 2004 and 2014 Benchmark minimum academic standards for undergraduate programmes in Nigerian universities support the adoption of innovative tools for library instruction and services in Nigerian universities. The Benchmark provided the opportunity for the library to adopt contemporary tools that enhance its services to the registered library patrons.

This current study explores some of the innovative tools including: ask-a-librarian, frequently asked question (FAQ), email services, text message, online public access catalogue (OPAC), Blogging and website among others. The adoption of innovativetools is synonymous with the dynamic nature of the library and its $21^{\text {st }}$ century users who are ICT savvy, skilful and willing to access the library and its services at any location. Furthermore, considering the homogeneity of the library patrons and their varied needs, this study is therefore designed to fill a gap with a view of providing theoretical approach. It is guided by three research questions:

1. What are the innovative tools used for library instruction and services in federal university libraries in South-South geo-political zone of Nigeria?

2. What is the frequency of use of innovative tools for library instruction and services in federal university libraries in South-South geo-political zone of Nigeria?

3. What are the Library services that are provided with innovative tools?

\section{Rationale for the study}

The delivery of library instruction and services takes different approaches across university libraries. The approach for the delivery of instruction may also depend on the availability of ICT tools and conducive environment. Irrespective of those factors, the purpose for instruction and services remain the same - increasing the research skill of the patrons in the use of information sources either in the 
library, database or the Internet. Many methodologies, theories and frameworks have been developed to evaluate the impact of library instruction on the library patrons (Spenser, 2003; Osinulu, 2003; Oparah, 2006; Association of College \& Research Libraries (ACRL), 2016) in order to get appropriate model. Such endeavours have not shown the use of innovative tools in library instruction and services in university library in Nigeria which means that there is a gap in literature. There is also some evidence in literature about methods that were used for the delivery of library instruction in Nigerian universities (Igwebuike \& Agbo, 2014; Omeluzor, Alarape, Dika \& Ukangwa, 2017).None of them has shown the use of innovative tools for the instruction of library patrons. However, some literature, for instance Madukoma, Onuoha, Omeluzor and Ogbuiyi(2013), Esse (2014) Ullah and Ameen (2014) have shown the use of traditional methods for library instruction to new and potential library users in the past with positive effects on the users (Shen, 2016). The traditional methods of library instruction are overwhelmed with challenges (Ogunmodede \& Emeahara, 2010; Suleiman, 2012; Esse, 2014). From the foregoing it is not out of place to conduct an investigation on the use of innovative tools for library instruction and services in the federal university library South-South, Nigeria. Hence, in a dynamic age and the dominance of ICT in the delivery of information services, it would be challenging to rely only on traditional methods for instruction without the use of innovative tools. This present study therefore investigates the use of innovative tools for library instruction and services in federal university library in South-South geopolitical zone of Nigeria.

\section{Literature Review}

There is evidence in study that university students (14 percent) of the total respondents used the services of librarians less often (Head, 2013). The finding in Head's study is an evidence of students' dependence on innovative tools for their research. Similarly, Stephens (2016) reported that students relied on librarians infrequently, if ever, whether they were conducting research for coursework or for personal use. Further results in Head (2013) necessitate the need for the adoption of innovative tools since fewer students (11 percent) out of the total sampled population required the assistance of a librarian. The study also showed that 7 percent wrote center staff for help, 5 percent turned to librarians for help for evaluating information for personal use, while 70 percent frequently turned to social networks, such as Facebook on information-seeking for personal needs. Furthermore, findings in Head's study showed that search engines such as Google received the highest patronage with 95 percent while friends had 87 percent as sources consulted by students for information. The finding may be attributed to the fact that library patrons are tilting towards the use of technology and innovative tools in their information search.

A recent study by Omeluzor, Alala and Omeluzor (2019) revealed a new approach for library instruction that was adopted at Clifford University Owerrinta, Nigeria. The approach is pedagogical in nature, combining ICTs and some innovative tools such as Google drive and other Google tools in teaching which exposed the learners to various ways of using ICT tools in learning and researching. Considering the nature of the $21^{\text {st }}$ century library users and the advancement in the use of ICT in library services, there is no contradiction in using innovative tools for the delivery of library instruction and services to library patrons who are predominantly studentsin the university library in Nigeria and other parts of the world.

The use of Web 2.0 tools is gaining acceptance in some libraries for instruction and service delivery (Kim \& Abbas, 2010). A few study such as Habib (2006) and Kim and Abbas (2010) have reported the use of Web 2.0 tools for library user instruction; however, its adoption and use in some federal university libraries in Nigeria is yet to be ascertained in literature showing a lacuna.Web 2.0 is a web-based technology that enables users to connect, communicate and collaborate with one another, forming on-line socialites and communities. Such technologies include Blogs, Wikis, RSS feeds, Audio-podcasting, content syndication, social bookmarking, tagging, social networking, multimedia 
sharing, bibliographic reference managers, chat, messaging and video conferencing (Kim \& Abbas, 2010). The use of Web 2.0 tools for library instruction would form an innovative hub for the library to take its services to the users. According to Habib (2006), the introduction of Web 2.0 tools into library web sites encourages interaction or communication between librarians and library patrons thus expanding the library services to the patrons who may be far away from the physical library building. In this study, the author concentrated on some specific innovative tools including: frequently asked question (FAQ), Text message, ask a Librarian, website, library Blog and OPAC for the delivery of library instruction and services in university libraries in South-South geo-political zone of Nigeria.

\section{Innovative Tools for Library Instruction and Services}

Several authors have represented innovative ideas in different ways in literature. The study of Corral and Jolly (2019) emphasizes a technologically-driven innovation including the use of tools that are relevant in the delivery of impactful instruction. Corral and Jolly (2019) furthernoted that the kind of innovation that is needed in the library of today is such as rethinking the instructional roles of librarians, collaborating with other professionals services, and contributing to changes in teaching and learning on their campus and beyond. A case study presented by Corral and Jolly (2019) in the use of innovative tools for instruction was the one by Mary Oberlies, Kristin Buxton and Annie ZeidmanKarpinski at the University of Oregon who selected three widely-used peer observation tools (Teaching Squares, the Teaching Practices Inventory and the Classroom Observation Protocol for Undergraduate STEM), adapted them to fit the need of library instruction. Similarly, Okeke and Chibueze (2020) proposed the use of Library Space as an innovative tool for effective reading and learning in academic libraries. Their paper anchored on the relevance of Library Space as innovative tool for creativity, learning and collaboration between librarians and patrons in the delivery of library instruction. Booth (2009:1) emphasized the contributions of the Reference and Instruction Department of Aiden Library for its innovative work with Skype reference, library wikis, customized browser toolbars, interactive FAQ knowledgebase and video reference kiosks. The integration of the innovative tools at Aiden Library enhances instruction and services to their library patrons. Similarly, the use of innovative tools at the University of Rochester allows students' "self-service" orientation which would give librarians additional time to handle other tasks in the library (Foster \& Gibbons, 2007). According to Andrew, Wright and Rasking (2016) innovative tools allow students to take responsibility and control over their own learning, bridges the in-class experience of students and promotes integration of e-literacy leaning. This present study is focusing on the popular tools that can be embedded on the library website of a university on the Internet.

\section{Frequently Ask Question (FAQ)}

This is a service that has some preconceived answers to hypothetical questions of problems that are usually encountered by library users. FAQ contain list of questions and relevant answers that are expected to provide solution to whatever query a library user may have. For instance, if one encounters difficulty in finding where to access an information material while using a library online public access catalogue (OPAC) such answer can be provided using the OPAC's FAQ. The answer to the query may lead the user where to find the needed document. FAQ can also be created for effective use of the library's institutional repository, electronic database and other services provided by the university libraryy. The Smithsonian Libraries, University of Wisconsin-Madison and National Library of Australia are among libraries that are using FAQ to provide library services and instructions to its patrons. Libraries that create FAQ as media for instruction and services may support their users beyond their library building and opening hours. 


\section{On-line Public Access Catalogue (OPAC)}

OPAC is a tool and feature of an integrated library system (ILS) that holds all processed bibliographic records of a library. It is a tool that provides on-the-spot services and access to information materials in a library. OPAC may be local or Web-based. Locally hosted OPAC is usually accessible to library users that are within a university's network via an institution's Intranet. On the other hand, a Webbased OPAC is accessible to everyone that is connected to the Internet and is usually accessible through a Universal Resources Locator (URL).A well customized OPAC would include feature that can be used to instruct and provide services to the library patrons on how to use both the OPAC and other library services. OPAC is helpful to know the availability and location of needed information sources in a library (Thanuskodi, 2012). An increasingly use of OPAC in academic libraries in Nigeria has been reported in literature (Fabunmi \&.Asubiojo, 2013)

\section{Text messaging}

Text messaging service also known as small message service (SMS) has become a practicable medium of information sharing among people. In Nigeria, the approval by the Nigerian Communication Commission (NCC) for mobile technology providers such as MTN, Globacom and Airtel among others to handle telecommunication operations has increased the use of cell phones for communication and information sharing among friends, associates, colleagues, and organizations. The service has been incorporated in some libraries. For instance: 'SMS a Librarian' has been customized to become part of the Ask a Librarian service at Southbank Institute Library which includes email, phone and live chat access for students and staff (Herman, 2007).SMS isdelivered in bulk as well as single to recipients. Bulk SMS is sent to a larger number of homogenous recipients with customized text while a single SMS is sent to a single recipient. SMS is less expensive especially when it is sent as bulk message. The library can take advantage of this means to provide library instruction and information services to its new and potential users. Study showed the use of SMS at Sims Memorial Library at South-Eastern Louisiana University known as: "Text a Librarian," a service that enables South-Eastern students, faculty, and staff to use the text message feature of their cell phones to send questions and receive answers from the library (Hill, Hill \& Sherman, 2007). Herman (2007) in his paper titled: "SMS reference: keeping up with your clients" found out that implementing SMS reference service allow the library the opportunity to communicate students via a familiar accessible services such as: circulation services, current awareness services, SDI services and reference services among others.

\section{Ask a Librarian}

This is a reference service that the library can adopt to provide instruction and service via the library website. It is a platform designed for users to ask questions, make inquiries and request for answers for specific services from librarian. Ask a Librarian is a live virtual reference service that offers online reference assistance to library users no matter the location. It also enhances communication between the users and Reference Librarian who receives such queries and provides direct answers to the users. The study by Fidelis (2018) showed that from total respondents of 40, 11 or 36.7\% administrative staff used Ask a librarian at UDSM Library, while a majority of 26 or $86.7 \%$ of administrative staff used chart a librarian in the library. Some university libraries for examples: University of Michigan Library, University of Illinois at Urbana Champaign Library ,University of Lagos and Federal University of Technology, Akure in Nigeria are now using Ask a Librarian for library user instruction both in international universities and Nigeria have reported using Ask a librarian to provide services to their library users. Also, Seattle Public Library reported using Ask a librarian feature to respond to 
users' query as well as instructing library users. However, no study has shown any evidence of the use of Ask a librarian in federal university libraries in South-South geo-political zone of Nigeria.

\section{Blogging}

This is an online platform for information sharing and dissemination. An individual, institution and organization can create Blog page on the Internet to reach out to people, business associates and non affiliates. University library can use the Blog as an 'online notice board' for posting of notices about their activities and up-coming events for its library patrons. Blog can be created and hosted freely using Google and Word Press applications on the Internet. Blog provides platform for online interaction between the host and visitors with feedback mechanism. Blogging is a potential medium for the university library to communicate effectively with its patrons in this digital era. Trivedi (2010) had proposed the use of Blog to provide commentary and information on a particular subject or act as a more personal online diary. There is evidence on the use of Blog in the University of Nigeria Nsukka, University of San Diego School of Law, Cornell University and Duquesne University School of Law are among universities.

\section{Social Media}

The use of social media (SM) is another buster for instruction and services in the library. According to Joe and Knight (2019), social media use for communication and instruction is an essential reference source that offers guidance that can be adopted by academic libraries for instruction with a special emphasis on assessment and evidence. Ferretti (2017) in her article titled: "bridging contemporary and social issues for information literacy through instructional platforms" noted that as the digital initiative librarian at the Maryland Institute College of Art (MICA) her focus was how to use technology to bridge contemporary and social issues with information literacy within the context of an art and design college curriculum. The paper revealed how Ferretti took time in researching for digital tools that could enhance library instruction in academic library. Accordingly, Omenka, a social media tools was reported to have been embedded with a curatorial focus in two art history classes that span one academic semester at MICA. Both classes were divided into curatorial teams charged with creating online exhibitions and interpretive texts (Ferretti, 2017). Also, the Indiana University Bloomington (2019) is increasingly using their IUB Libraries media services to help their patrons in media literacy. The University also have a fair amount of related campus media support services, such as: University Information Technology Services and Center for Innovative Teaching \& Learning. Use of those innovative tools has proven effective and faster in the delivery of library instruction and services to the patrons.

\section{Frequency of Use of Innovative Tools for Library Instruction}

The frequency of use of innovative tools in the library is gradually increasing from what it was in the past. The study by Ossai-Ugbah (2010) on the use of automated library services in Nigerian universities revealed that the frequency of use for instruction is at an average level. According to Booth (2009:94) the older people are proportionately more receptive to library services that are offered via innovative platforms. This is because the older people are more attentive without distractions. Balog, Siber and Plašćak (2013) on the outcome of library instruction focusing on students' information literacy (IL) at two Croatian academic institutions showed that the sampled students realized the benefit of the library instruction for their IL skills. The finding also showed an improved skill that increases the frequency of usage among the respondents in searching the library catalog, databases and search strategies. Although, the respondents were quite critical about their search strategies, but at the end of the instruction class, there was improvement in their IL skills. 
Similarly, Bowles-Terry (2012) used a mixed method of assessment on a library instruction program to investigate how library instruction can increase frequency of use of information sources and leading to students' academic success. The finding showed that all the students in the focus group discussed specific skills or tools that were learnt during library instruction session that enhance their research projects. In another development, the ACRL report of 2017 prepared by Karen Brown using multiple data points (e.g., circulation, library instruction session attendance, online database access, study room use, interlibrary loan) revealed that students who used the library in some way achieved higher levels of academic success (e.g., GPA, course grades, retention) than students who did not use the library. It further showed that library instruction improves students' achievement of institutional core competencies and general education outcomes.

\section{Methodology}

This study investigated the use of innovative tools for library instruction and services in Federal University Libraries in South-South geo-political zone of Nigeria. The study adopted a survey research design. A purposive sampling technique was used to select all the Federal Universities in the South-South geo-political zone of Nigeria. There are six (6) federal universities with a total population of 93 librarians as shown in Table 1. The sampling technique used was total enumeration. This was because the entire population of 93 librarians was considered appropriate in achieving the purpose of the study. According to Iwuanma, Ohen, Ogbebor and Onwuegbu (1992), an entire population can be used as the sample in a study when time and resources are available and when the study seeks specifically to determine attributes of the population. The instrument for data collection was a questionnaire. The instrument has four sections. Section A covered the demographic information of the respondents. Section B, C and D provided information on the innovative tools used, level of usage and the frequency of use for library instruction and services. Section B and C were adopted from a similar study conducted by Omeluzor, Imam and Gbemi-Ogunleye (2018) while Section D was developed by the researchers.A pilot approach was adopted to test the reliability of the instrument. The Cronbach Alpha result reveals $r=78$ which shows that the instrument is reliable since it is above the set 0.05 acceptable level, and was to be administered on the same type of respondents at a different geographical location. The questionnaire was administered on all the respondents faceto-face by the researchers with the help of two (2) research assistants who were taught by the researchers on how to administer and retrieve questionnaire. The entire questionnaire were retrieved and were found usable for the study. Section B has a 3-1 scale point with 3 as the highest and 1 the lowest, section $\mathrm{C}$ has 5-1 scale point with 5 being the highest and 1 the lowest while section $\mathrm{D}$ has 4-1 scale point with 4 the highest and 1 the lowest. The questionnaire was analysed using Statistical Package for Social Science (SPSS) version 7.0. Descriptive statistics of frequency counts, percentage, mean and standard deviation were used for the analysis and presentation of results for clarity and proper understanding. Note that for Tables 2, 3and 4, the decision rule is: Mean is $01-1.9=$ very low, 2.0-2.4 = low, $2.5-2.9=$ high, 3.0 and above =very high

Table 1: Federal Universities in South-South Geo-Political Zone of Nigeria, State of location and Number of Librarians

\begin{tabular}{lll}
\hline University & State & No. of Librarians \\
Federal University of Petroleum Resources, Effurun & Delta & 09 \\
Federal University Otuoke & Bayelsa & 12 \\
University of Benin & Edo & 26 \\
University of Calabar & Cross Rivers & 12 \\
University of Port-Harcourt & Rivers & 19 \\
University of Uyo & Akwa Ibom & 15 \\
Total Population of Librarians & & 93 \\
\hline
\end{tabular}




\title{
Presentation of Findings
}

\section{Demographic Information of Respondents}

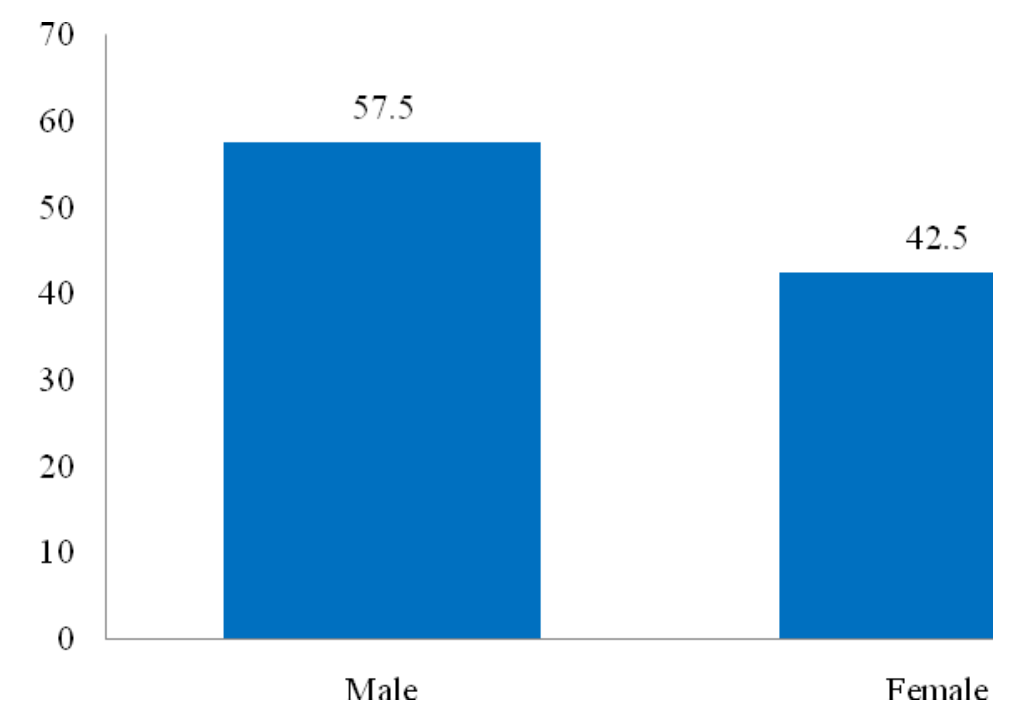

Fig.1: Gender of Respondents

On the gender of the respondents, the result in Figure 1 shows that among the respondents in this study, 57.5 percent are male while 42.5 are female. This means there are more male in this study than their female counterpart.

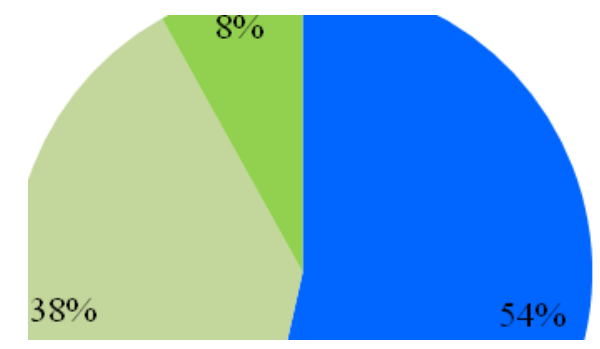

\author{
- Bachelors Degree \\ Masters Degree \\ $\square$ Ph.D.
}

Fig.2: Academic Qualification of Respondents

The result in Figure 2 reveals the academic qualification of the respondents. It shows that 54 percent of the respondents are Bachelors' Degree holder, followed by 38 percent and 8 percent of the respondents with Masters Degree and Ph.D. respectively. 


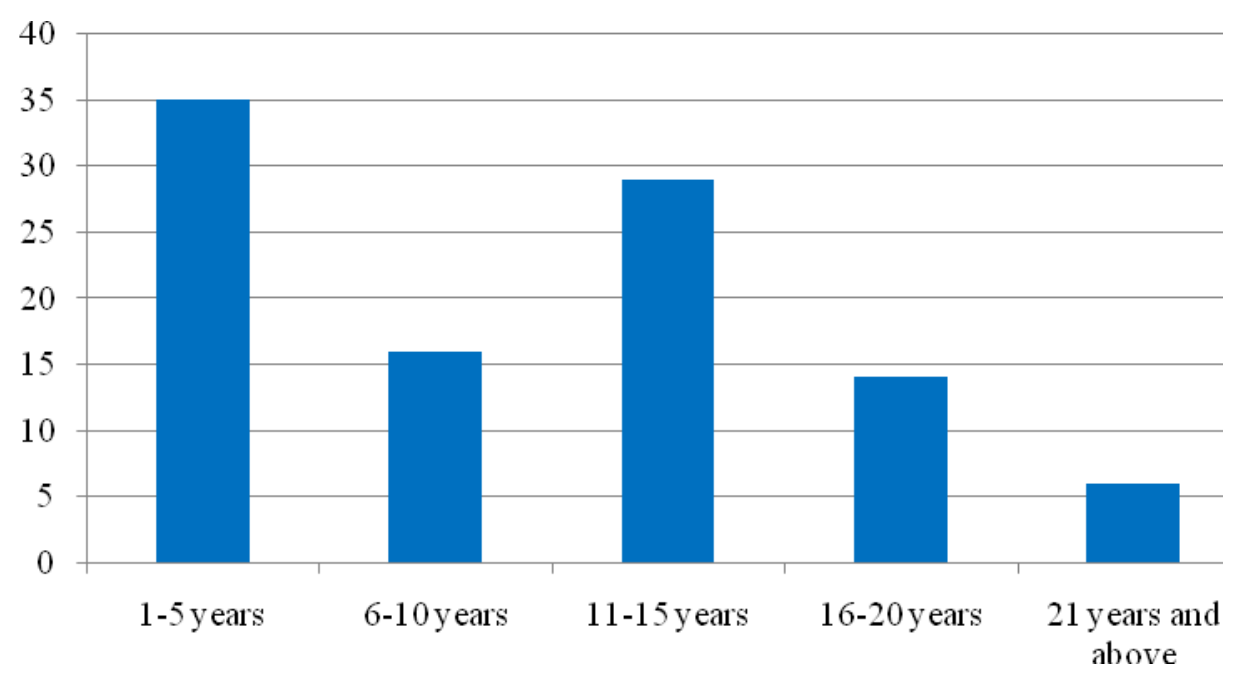

Fig. 3: Respondents' Years of Service

The result in Figure 3 shows that 35 percent of the respondents have worked between 1-5 years. This is followed by 16 percent of the respondents who have worked between 6-10 years. It also revealed that 29 percent of the respondents have worked between 11-15 years while 14 percent of the respondents have worked between 16-20 years. The remaining 6 percent of the respondents as shown in fig. 3 indicated to have work for 21 years and above.

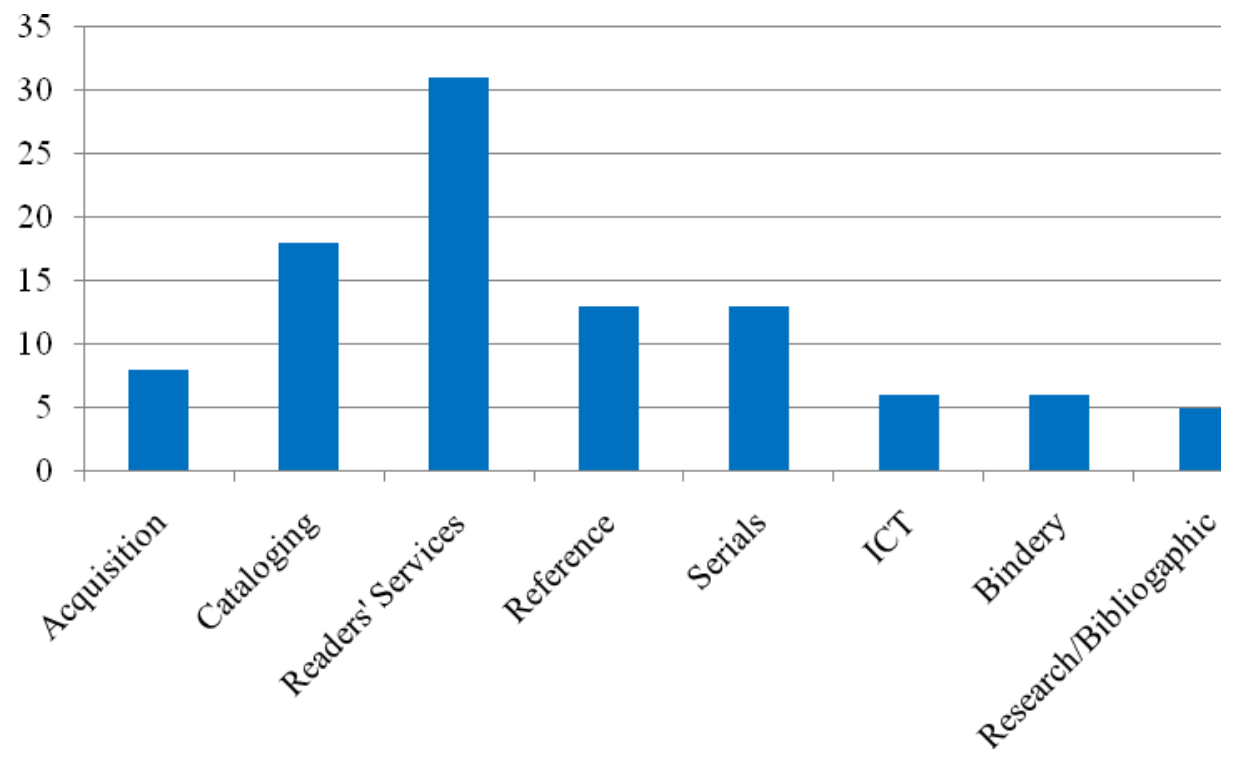

Fig. 4: Library Section of Engagement by Respondents

The result in Figure 4 reveals that 8 percent of the respondents are acquisition librarians, 18 percent are cataloguers, 31 percent are readers' services librarians, 13 percent are reference and serial librarians respectively, 6 percent works in ICT and bindery sections respectively while 5 percent of the respondents work in research and bibliographic sections. This result indicates that more of the workforce is found in the Readers' services meaning that it may have attracted more traffic to warrant such number of staff strength. 
Research question 1: What are the innovative tools used for library instruction and services in federal university libraries in South-South zone of Nigeria?

Table 2: Innovative tools used for library instruction in university libraries

\begin{tabular}{|c|c|c|c|c|c|}
\hline Media & Mostly Used & Not used & Not aware & $\bar{X}$ & Std. Dev. \\
\hline Ask a Librarian & $2(2.2)$ & $25(26.9)$ & $66(71)$ & 1.31 & 0.51 \\
\hline Email & $39(41.9)$ & $48(51.6)$ & $6(6.5)$ & 2.35 & 0.60 \\
\hline Frequently ask question (FAQ) & $5(4.4)$ & $84(90.3)$ & $4(4.3)$ & 2.02 & 0.36 \\
\hline Library Blog & $31(33.3)$ & $23(24.7)$ & $39(41.9)$ & 1.91 & 0.86 \\
\hline Library Website & $28(30.1)$ & $65(69.9)$ & - & 2.30 & 0.46 \\
\hline $\begin{array}{l}\text { Online Public Access Catalogue } \\
\text { (OPAC) }\end{array}$ & $13(14)$ & $73(78.5)$ & $7(7.5)$ & 2.06 & 0.46 \\
\hline Radio broadcasting & - & $70(75.3)$ & $23(24.7)$ & 2.46 & 0.65 \\
\hline Social media & $51(54.8)$ & $42(45.2)$ & - & 2.54 & 0.50 \\
\hline Text message & $59(63.4)$ & $34(36.6)$ & - & 2.63 & 0.48 \\
\hline Video conferencing & - & 27 (29) & $66(71)$ & 1.29 & 0.45 \\
\hline
\end{tabular}

Key: $\overline{\mathrm{X}}=$ Mean, Std. Dev. = Standard Deviation

The result in Table 2 reveals that among the innovative tools in this study, only two including social media $(\overline{\mathrm{X}}=2.5)$, text messaging $(\overline{\mathrm{X}}=2.6)$ are used more often than the others. It also shows that email ( $\overline{\mathbf{X}}=2.3$ ) is also used but not more often. Result shows a scanty use of library Blog and Library website and a general none use of Radio broadcasting and video conferencing with poor use of Ask a Librarian, FAQ and OPAC for library instruction and services. The resulting in Table 2 further reveals a higher and significant number of the respondents who indicates that they have "not used" most of the items in the table. This scenario is an indication of inadequate use of innovative tools for library instruction and services in the South-South geo-political zone of Nigeria.

Research question 2: What is the frequency of use of innovative tools for library instruction and services in federal university libraries in South-South zone of Nigeria?

Table 3: Frequency of use of innovative tools for library instruction and services

\begin{tabular}{|c|c|c|c|c|c|c|c|}
\hline Media & Daily & Weekly & Monthly & Quarterly & Not at All & $\bar{X}$ & $\begin{array}{l}\text { Std. } \\
\text { Dev. }\end{array}$ \\
\hline Ask a Librarian & $4(4.3)$ & - & - & - & $89(95.7)$ & 1.17 & 0.81 \\
\hline Email & - & $63(67.1)$ & - & - & $30(32.3)$ & 3.03 & 1.40 \\
\hline $\begin{array}{l}\text { Frequently } \\
\text { Question (FAQ) }\end{array}$ & $4(4.3)$ & - & - & - & 89 (95.7) & 1.17 & 0.81 \\
\hline Library Blog & - & - & - & $93(100)$ & - & 1.47 & 0.56 \\
\hline Library Website & - & - & $4(4.3)$ & 89 (95.7) & - & 1.08 & 0.40 \\
\hline $\begin{array}{l}\text { Online Public Access } \\
\text { Catalogue (OPAC) }\end{array}$ & - & - & - & $63(67.7)$ & $30(32.3)$ & 1.70 & 0.87 \\
\hline Radio broadcasting & - & - & - & - & $93(100)$ & 1.00 & 0.00 \\
\hline Social media & $67(72)$ & - & $4(4.3)$ & - & $22(23.7)$ & 3.96 & 1.70 \\
\hline Text message & $63(67.7)$ & $4(4.3)$ & $4(4.3)$ & - & $22(23.7)$ & 3.92 & 1.69 \\
\hline Video conferencing & - & - & $4(4.3)$ & $27(29)$ & $62(66.7)$ & 1.37 & 0.56 \\
\hline
\end{tabular}

Key: $\overline{\mathrm{X}}=$ Mean, Std. Dev. = Standard Deviation

The result in Table 3 reveals that majority of the respondents (72 and 67.7 percent) use social media and text message daily for library instruction and services. Another majority (67.7 and 67.1 percent) use email weekly for library instruction and services. The result in Table 3 also shows a quarterly use of Library Blog, Website and OPAC for instruction and services. The result imply that Federal University Libraries in South-South of Nigeria have adopted some innovative tools for library instruction and provision of services to its patrons. Result in Table 3 also shows a general none use of 
radio broadcasting and lower use of Ask a Librarian and FAQ in the delivery of library instruction and services on a daily, weekly, monthly or quarterly basis.

Research question 3: What are the Library services that can be provided with innovative tools?

Table 4: Library Services provided with innovative tools

\begin{tabular}{|c|c|c|c|c|c|c|}
\hline Statement & SA & A & $\mathrm{D}$ & SD & $\overline{\mathrm{X}}$ & $\begin{array}{l}\text { Std. } \\
\text { Dev. }\end{array}$ \\
\hline Circulation Services (CS) & $62(66.7)$ & $29(31.2)$ & $2(2.2)$ & - & 3.64 & 0.52 \\
\hline Current Awareness (CA) & $46(49.5)$ & $46(49.5)$ & $1(1.1)$ & - & 3.48 & 0.52 \\
\hline Email Services (ES) & $43(46.2)$ & $49(52.7)$ & $1(1.1)$ & - & 3.45 & 0.52 \\
\hline Inter-library loan (ILL) & $57(61.3)$ & $33(35.5)$ & $3(3.2)$ & - & 3.58 & 0.55 \\
\hline Internet services (IS) & $28(30.1)$ & $35(37.6)$ & $25(26.9)$ & $5(5.4)$ & 2.92 & 0.88 \\
\hline Loan Services (LS) & 38 (40.9) & $52(55.9)$ & $3(3.2)$ & - & 3.37 & 0.54 \\
\hline Reference Services (RS) & $57(61.3)$ & $33(35.5)$ & $3(3.2)$ & - & 3.58 & 0.55 \\
\hline Reprographic Services (RpS) & - & $15(16.1)$ & $51(54.8)$ & $27(29)$ & 1.87 & 0.66 \\
\hline $\begin{array}{l}\text { Selective Dissemination } \\
\text { Information (SDI) }\end{array}$ & of $40(43)$ & $52(55.9)$ & $1(1.1)$ & - & 3.41 & 0.51 \\
\hline
\end{tabular}

Key: $\mathrm{SA}=$ strongly agree, $\mathrm{A}=$ Agree, $\mathrm{D}=$ disagree, $\mathrm{SD}=$ strongly disagree, $\overline{\mathrm{X}}=$ Mean, Std. Dev. $=$ Standard Deviation

The result in Table 4shows that a majority of the respondents use innovative tools to provide most of the library services to the library patrons. The result reveals that a majority of the respondents acceptance that they provided CS, CA, ES, ILL, IS, LS, RS and SDI services to the patrons. Among the services: circulation services $(\overline{\mathrm{X}}=3.64), \mathrm{CA}=(\overline{\mathrm{X}}=3.48)$, email services $(\overline{\mathrm{X}}=3.45)$, interlibrary loan services $(\overline{\mathrm{X}}=3.58)$, internet services $(\overline{\mathrm{X}}=2.92)$, loan services $(\overline{\mathrm{X}}=3.37)$, Reference services $(\overline{\mathrm{X}}=3.58)$ and SDI $(\overline{\mathrm{X}}=3.41)$ excluding reprographic services with $(\overline{\mathrm{X}}=1.87)$ are provided using innovative tools. The result in Table 4 implies that innovative tools are effective and relevant in the delivery of services, and if properly harnessed would help in reducing waste of time, cost and stress involved in library service delivery to the patrons.

\section{Discussion of findings}

There is evidence in Table 2 which reveals the use of innovative tools such as social media and text message for library instruction and services. Engaging the library patrons with innovative tools would foster collaboration between Librarians and users as well as patronage in the use of library resources. It would also help in reaching the users at any location thereby increasing the awareness of available information sources and services. The finding in Table 2 agrees with the findings in Omeluzor, Oyovwe-Tinuoye and Imam (2016) which showed that 83 percent of the respondents agreed that innovative tool such as online social network has the potential to communicate and send out information to the library users. In addition, the use of innovative tool for library instruction and services has been reported in many literature (Corral \& Jolly, 2019; Okeke \& Chibueze, 2020), that help students to take responsibility and control over their own learning and bridging the in-class experience of students (Andrew, Wright \& Rasking, 2016). Findings in Table 2 also confirm the findings in the study of Omeluzor, Imam and Gbemi-Ogunleye (2018) which showed that text message, email and social media are used for library services while radio broadcasting, video conferencing and FAQ are not maximized in the delivery of library services. Evidence on the Internet has shown that there are some universities around the world that have adopted innovative tools for library instruction and services. For instance: University of Oregon, University of San Diego, School of Law and Duquesne University School of Law use Blogs to update and instruct library users on how to use the library and its information sources. 
From the findings in Table 3, it shows that the frequency in the e use of innovative tools such as email, FAQ, library website for library instruction and services is low with a general non-use of radio broadcasting. It also shows that 71 percent are not aware that Ask a Librarian and video conferencing can be used for library instruction and services. The infrequent use of innovative tools for instruction and services would affect service delivery to the users. The $21^{\text {st }}$ century library users may also be underserved considering their technological savvy without using innovative tools in service delivery. The finding is against the findings of Omeluzor, Imam and Gbemi-Ogunleye (2018). This implies that the federal university libraries in South-South of Nigeria are yet to fully adopt innovative tools for library instruction and services. The implication of none use of innovative tools for library instruction and services would be a continuous use of traditional methods which may not satisfy the information needs of the $21^{\text {st }}$ century library patrons. It may also impact negatively on the services of the library for those patrons who are dispersed at different locations. Another negative effect of none use of innovative tools is that it may breed discouragement among users who may be attracted to other available platforms that meet their information needs.

Finding in Table 4 reveals that the use of innovative tools enhances the provision of all the services listed in the Table 4 except reprographic services. The finding increases the relevance of innovative tools as a medium that the library can use for the in delivery of library services to the patrons irrespective of their location. The findings in Table 4 shows that critical services including CS, CA, ES, ILL, IS, LS, RS and SDI can easily be handled using innovative tools as attested by a majority of the respondents. The finding corroborates with the report of Seattle Public Library that used Ask a librarian feature to respond to users' query, provided services and instruction to the library users. The findings also confirms the commendation of the Reference and Instruction at the Department of Aiden Library for its innovative work with the use of innovative tools such as Skype reference, library wikis, customized browser toolbars, interactive FAQ knowledge base and video reference kiosks to deliver library services cutting across CS, CA, SDI and ILL among others (Booth, 2009:1). The finding implies that the tools are relevant in facing today's reality while none use of it would hamper access for the delivery of quality services to the library patrons.

\section{Conclusion and Recommendations}

The university library is a dynamic institution that changes with advancement in technology. The use of innovative tool for library instruction and services is gradually being accepted in academic libraries in South-South zone of Nigeria. Although, the result shows that there is a decrease to fully adopt some of the innovative tools that are revealed in literature. Inadequate use of innovative tools would hamper the delivery of quality library services to the patrons. The frequency in the use of text message, OPAC, social media and email in library instruction and services spanning between daily and weekly is encouraging. While there are evidence of increasing use of some innovativetools, there is no doubt that some university libraries are yet to adopt it for instruction and services. However, it is important to state that the use of innovative tool for library instruction and services wouldimpact positively on both the librarians and library users. For the librarians, it would increasetheir ICT skill, moral and delivery of library services, while for the users, it would increase their knowledge, patronage and access to library sources and services either within and outside the university library. All library users including staff, researchers and students would feel the impact of the library should the library consistently interact and engages them with innovative toolhence providing the library an opportunity for advocacy. In view of the findings in this study the following recommendations are made:

1. There is the need for the library management in Nigeria and other part of the world to encourage librarians in using innovative tools for library instruction and services as consistent use may help in reaching out to more users as well as increasing their ICT skill in the use of other online sources. 
2. Federal university libraries in the South-South zone of Nigeria should collaborate with their ICT Department in the development of web applications that can help in promoting their services to their patrons on the Internet.

3. Librarians in the university libraries in South-South zone of Nigeria should be encouraged to explore viable innovative tools for library instruction and service delivery to their library patrons.

4. The university library management in South-South zone of Nigeria should organize routine trainingprogramme for thelibrarians on the use of innovative tools to enable them acquire relevant skills in handling library instruction and services.

\section{References}

Andrew, C., Wright, W.E, \& Rasking, H. (2016). Library learning spaces: Investigating libraries and investing in student feedback. Journal of Library Administration, 56 (6),

Booth, C. (2009). Information Innovation: Tracking Student Interest in Emerging Library Technologies at Ohio University.

Bowles-Terry, M. (2012). Library instruction and academic success: A mixed - methods assessment of a library instruction program. Evidence Based Library and Information Practice 7 (1): 82-95

Cornell University Library (2015) Current awareness. Retrieved from:https://www.library.cornell.edu/research/current-awareness

Corral, S. \& Jolly, L. (2019). Innovations in learning and teaching in academic libraries: Alignment, collaboration, and the social turn. New Review of Academic Librarianship, 25, 2-4. https://doi.org/10.1080/13614533.2019.1697099

Duquesne University School of Law (2016). Publications \& Blogs. Retrieved from http://law.duq.edu/student-life/publications-blogs

Esse, U. C. (2014). Effects of library instruction on satisfaction with the use of library and itsservices: A study of undergraduate students in five universities in the Southern part ofNigeria. European Scientific Journal, 10(13), 441-450.

Fabunmi, O. M. \& Asubiojo, B. O. (2013). Awareness and use of online public access catalogue by students of Obafemi Awolowo University, Ile-Ife, Nigeria. Library Philosophy and Practice (ejournal). Paper 922. Retrieved from http://digitalcommons.unl.edu/libphilprac/922

Fidelis, A. (2018). Usage of information and communication technology to support innovative library services in universities: A case of the University of Dar es Salaam Wilbert Chagula Library. University of Dar es Salaam Library Journal, 13(2), 3-17.

Foster, N \& Gibbons, S. (2007).Studying students: The undergraduate research project at the University of Rochester. Chicago: Association of Research Libraries. Retrieved from http://docushare.lib.rochester.edu/docushare/dsweb/View/Collection-4438

Habib, P. B. (2006). A theory of religious accommodation. Journal of Applied Philosophy. 23 (1), $109-126$.

Head, A. J. (2013). How freshmen conduct course research once they enter college.Retrieved June from http://projectinfolit.org/images/pdfs/pil_2013_freshmenstudy_fullreport.pdf

Herman, S. (2007). SMS reference: keeping up with your clients. The Electronic Library. Retrieved from https://www.emerald.com/insight/content/doi/10.1108/02640470710779817/full/html

Hill, J.B., Hill, C. M. \& Sherman, D. (2007). Text Messaging in an Academic Library: Integrating SMS into Digital Reference. The Reference Librarian, 47 (1), 17-29, DOI: 10.1300/J120v47n97_04, Retrieved from https://www.researchgate.net/publication/254374907_Text_Messaging_in_an_Academic_Libra ry_Integrating_SMS_into_Digital_Reference 
Igwebuike, A.D. \& Agbo, E.U. (2014). Inculcating information literacy skills in Nigerian university students: The foundation for independent lifelong learning. J. Educ. Pract., 5(39), 19 -24.

Iwuanma, B.C., Ohen, E.R., Ogbebor, G.C. \& Onwuegbu, O.C. (1992). Research methods in education. Benin City: World of Book Publishers.

Joe, J \& Knight, E. (2019). Social media for communication and instruction in academic libraries. Retrieved from https://www.igi-global.com/book/social-media-communication-instructionacademic/214080

Kim, Y. M. \&Abbas, J. (2010). Adoption of library 2.0 functionalities by academiclibraries and users: A knowledge management perspective. Journal of AcademicLibrarianship 36(3): 211-218.

Libraries, University of Wisconsin-Madison (2019). Frequently asked questions. Retrieved from https://www.library.wisc.edu/digital-library-services/minds/faq/

Madukoma, E., Onuoha, U.D., Omeluzor, S. U. \& Ogbuiyi, S. (2013). Library instruction and academic performance of undergraduates at Babcock University, Nigeria. Contemporary Humanities, 6, 39-58.

National Library of Australia (2019). Frequently asked questions. Retrieved from https://www.nla.gov.au/faq

National Universities Commission (2007). Benchmark minimum academic standards for undergraduate programmes in Nigerian universities. Retrieved from: https://www.fuotuoke.edu.ng/sites/default/files/F-BMAS\%20Administration.pdf

National Universities Commission (2014). Benchmark minimum academic standards for undergraduate programmes in Nigerian universities: Social Sciences. Retrieved from: http://eprints.covenantuniversity.edu.ng/8484/1/Social\%20Sciences\%20Draft\%20BMAS.pdf

Ogunmodede, T. A. \& Emeahara, E. N. (2010). The effect of library use education as acourse on library patronage: A case study of LAUTECH Library, Ogbomoso, Nigeria. Retrieved from http://digitalcommons.unl.edu/libphilprac/426/

Okeke, I. \& Chibueze, M.N. (2020). Innovative use of Library Space as a tool for effective reading and learning in academic libraries. Retrieved from https://researchgate.net/publication/340547595

Omeluzor, S.U., Alala, A.G. \& Omeluzor, G. U. (2019). Integration of ICT in library instruction in Clifford University, Owerrinta, Nigeria: A Study. DESIDOC Journal of Library \& Information Technology, 39 (4), 192-198, DOI : 10.14429/djlit.39.4.13790

Omeluzor, S.U., Imam, A. \& Gbemi-Ogunleye, P. (2018). Innovative tools for Library Users Instruction in Academic Libraries in South-West, Nigeria, In Changing the Scope of Library Instruction in the Digital Age. IGI Publishers, USA. Pp.162-185. DOI: 10.4018/978-1-52252802-9.ch007

Omeluzor, S.U., Oyovwe-Tinuoye, G.O. \& Imam, A. (2016). Social networking tools in library service delivery: The case of academic libraries in South-East zone of Nigeria. DESIDOC Journal of Library \& Information Technology, 36 (5), 269-277. DOI: 10.14429/djlit.36.5.10174

Oparah, U.N. (2006). Integration of ICT in the reference services curricula of Nigerian library and information science schools. The Information Technologist 3(1): 27-35.

Osinulu, L.F. (2003). Undergraduate Library instruction at the Olabisi Onabanjo University.Lagos Journal of Library and Information Science, 2(1 ):11-15.

Ossai-Ugbah, N.B. (2010). The impact of automated library services and usage on student's academic performance in Nigerian universities. International Journal of Library and Information Science, 2(9), 169-176. 
Shen, L. (2016). Both online and in-person library orientations have positive effects ongraduate students' information literacy skills. Evidence Based Library and InformationPractice, 11(2), 189-191.

Smithsonian Libraries (2019). Frequently asked questions - Ask a Librarian. Retrieved from https://library.si.edu/research/faq

Spenser, T. (2003). Information literacy meeting of expert: Conference report Prague: USNational Commission on Libraries and Information Science and the National Forum onInformation Literacy with the support of UNESCO. Retrieved fromhttp://portal.unesco.org/ci/en/files/19634/11228859241Prague_Final_Report_1210033.doc/Prague percent2BFinal percent2BReport percent2B percent2B12-10-033.doc

Stephens, M. (2016). The Heart of Librarianship Attentive, Positive and Purposeful Change. Retrieved from http://www.alastore.ala.org/pdf/9780838914540_sample.pdf

Suleiman, S. A. (2012). User education programs in academic libraries: The experience of theInternational Islamic University Malaysia students. Library Philosophy and Practice.Retrieved fromdigitalcommons.unl.edu/cgi/viewcontent.cgi?article=1851\&context=libphilprac

Thanuskodi, S. (2012). Use of online public access catalogue at Annamalai University Library. International Journal of Information Science, 2(6), 70-74.

The Association of College \& Research Libraries (ACRL) (2016). Framework forinformation literacy for higher education. Retrieved from http://www.ala.org/acrl/standards/ilframework

The Association of College \& Research Libraries (ACRL) (2017). Academic Library Impact on Student Learning and Success: Findings from assessment in action team project. Retrieved from http://www.ala.org/acrl/sites/ala.org.acrl/files/content/issues/value/findings_y3.pdf

Trivedi, M. (2010). Blogging for Libraries and Librarians. Library Philosophy and Practice (ejournal). Retrieved from: https://digitalcommons.unl.edu/libphilprac/380

University of San Diego School of Law (2016). Publications and Blogs. Retrieved from https://www.sandiego.edu/law/school/publications/ 